\title{
KEUANGAN PUBLIK ISLAM: ZAKAT SEBAGAI INSTRUMEN UTAMA KEUANGAN NEGARA
}

\author{
${ }^{1}$ Rifyal Zuhdi Gultom, ${ }^{2}$ Muhammad Rafi Siregar, ${ }^{3}$ Masrizal \\ 12 Magister Sains Ekonomi Islam, Fakultas Ekonomi dan Bisnis, Universitas \\ Airlangga, Surabaya
}

\author{
Alamat: Jl. Purnawirawan No 17 D, Dusun X, Medan Estate, Medan, Sumatera \\ Utara \\ No Hp: 085322608433 \\ E-mail: rifyalgultom@gmail.com
}

\begin{abstract}
Abstrak
Islam sebagai agama yang memuat ajaran yang bersifat komprehensif. Komprehensif memiliki arti bahwa ajaran Islam mencakup seluruh dimensi kehidupan baik sosial, ekonomi, politik, dan lainnya. Berkaitan dengan aspek ekonomi, maka salah satunya adalah keuangan publik Islam. Keuangan publik Islam merupakan sebuah kaidah dan prinsip yang mengatur keuangan publik untuk kepentingan masyarakat yang tujuan dasarnya adalah untuk mencapai falah. Nilai-nilai yang berasal dari Al-Qur'an dan Hadist yang menjadi dasar dari perumusan sistem keuangan dan kebijakan fiskal negara. Seiring dengan perkembangan zaman, keuangan publik Islam mengalami pembaharuan. Walaupun demikian, mekanisme pengelolaan keuangan publik khususnya kebijakan fiskal tetap dibangun atas dasar prinsip yang sesuai dengan tujuan Islam baik dari segi penerimaan maupun pengeluarannya.
\end{abstract}

Kata Kunci: Keuangan Publik Islam, Fiskal Islam, Zakat.

\section{Abstract}

Islam as a religion that contains teachings that are comprehensive. Comprehensive means that the teachings of Islam cover all dimensions of life whether social, economic, political, and others. Related to economic aspects, one of them is Islamic public finance. Islamic public finance is a principle and principle governing public finance for the benefit of the community whose basic purpose is to achieve falah. The values derived from the Qur'an and Hadith are the basis of the formulation of the country's financial system and fiscal policy. Along with the times, Islamic public finance is undergoing renewal. Even so, 
the mechanism for managing public finances, in particular fiscal policy, is still built on principles that are in line with Islamic objectives, both in terms of revenues and expenditures.

Keywords: Islamic Public Finance, Islamic Fiscal, Zakat

\section{PENDAHULUAN}

Islam sebagai agama yang memuat ajaran yang bersifat universal dan komprehensif (kaffah). Universal memiliki arti bahwa ajaran Islam dapat diterima oleh seluruh manusia atau masyarakat baik nilai keadilan, musyawarah, dan amanah. Sedangkan komprehensif berarti bahwa ajaran Islam mencakup seluruh dimensi kehidupan baik sosial, ekonomi, politik, budaya, maupun aspek-aspek lain. Pada dasarnya, Islam mempunyai tiga unsur utama, yaitu akidah, akhlak, dan syariah. Adapun syariah memiliki dua aspek dasar, yaitu ibadah dan muamalah. Ibadah merupakan suatu aktivitas yang berkaitan dengan penghambaan diri kepada Allah, sedangkan muamalah adalah suatu aktivitas yang berhubungan dengan interaksi antara sesama manusia termasuk untuk memenuhi kebutuhan hidupnya, termasuk salah satunya aktivitas ekonomi. Begitu banyak firman Allah yang mengatur manusia tentang bagaimana cara melaksanakan aktivitas ekonomi dengan baik, yang pada intinya adalah untuk mendapatkan keridhoan dari Allah SWT.

Penelitian ini membahas mengenai keuangan publik dalam konsep Islam khususnya kebijakan fiskal. Secara umum, jika berbicara tentang keuangan publik dalam Islam maka secara tidak langsung berbicara mengenai bagaimana sebuah negara mengelola keuangan baik dari sisi penerimaan maupun pengeluaran dengan cara yang baik, sesuai dengan pedoman syariat Islam. Selain itu, juga berbicara mengenai kepentingan masyarakat secara menyeluruh. Dengan adanya masyarakat tentu tidak terlepas dari peranan pemerintah dan masyarakat yang bersinergi untuk mengatur sistem kehidupan. Untuk itu, dibutuhkan suatu prinsip yang menjadi pedoman atas pelaksanaan keuangan publik berdasarkan nilai-nilai Islam. Prinsip yang dilaksanakan tersebut harus disesuaikan dengan tujuan yang hendak dicapai oleh suatu pemerintahan yang Islami sebagaimana yang menjadi tujuan dalam agama Islam yaitu untuk mencapai falah.

Negara merupakan otoritas tertinggi dalam merumuskan suatu kebijakan. Kebijakan pemerintah yang kerap kali bersinggungan langsung dan mempengaruhi iklim aktivitas masyarakat adalah kebijakan di bidang ekonomi. Salah satu kebijakan penting yang berada di dalam otoritas pemerintah adalah kebijakan fiskal, dimana negara berperan dalam mengatur kegiatan ekonomi agar tetap terjaga stabilitas keuangan yang secara tidak langsung berhubungan 
dengan kesejahteraan rakyatnya, sehingga dapat membantu untuk mengatasi persoalan fundamental yang kompleks.

Di dalam catatan sejarah peradaban Islam, negara juga difungsikan sebagai pemegang peran vital dalam mengatur kebijakan ekonomi yang dibangun di atas prinsip kemaslahatan dan kesejahteraan rakyat. Bentuk peran negara dalam sejarah Islam atas masalah ini diatur melalui institusi Baitul Maal. ${ }^{1}$ Rasulullah SAW membangun sebuah negara yang berlandaskan nilai-nilai Islam yang dikenal dengan nama Negara Madinah. Negara ini dibangun berdasarkan semangat keislaman yang tercermin dari Al-Qur'an dan kepemimpinan Rasulullah SAW. Seluruh aspek kehidupan masyarakat disusun berdasarkan nilai-nilai Qur'ani seperti persaudaraan, persamaan, kebebasan, dan keadilan. Sistem keuangan negara pun baru dibangun setelah melakukan berbagai upaya stabilisasi di bidang sosial, politik serta pertahanan keamanan negara. Pada masa awal pemerintahan, Negara Madinah hampir tidak memiliki sumber pemasukan. Demikian juga kebijakan fiskal belum banyak berperan dalam kegiatan perekonomian negara. Kebijakan fiskal belum banyak dijalankan karena memang belum ada pemasukan negara pada saat itu. Penerimaan pemerintah hanya berasal dari sumbangan masyarakat. Zakat pun belum diwajibkan ketika itu.

Dewasa ini, seiring dengan perkembangan zaman maka sistem keuangan mengalami perubahan, tidak terkecuali sistem keuangan publik Islam. Walaupun demikian, mekanisme pengelolaan keuangan publik Islam tersebut yang dibangun tetap menanamkan prinsip-prinsip yang sesuai dengan tujuantujuan Islam baik dari segi penerimaan maupun pengeluarannya. Untuk itu, tulisan ini akan membahas mengenai prinsip-prinsip keuangan publik Islam yang didasarkan dari sejarah keuangan publik Islam masa lampau untuk ditarik ke masa kini berdasarkan nilai-nilai yang tersirat di dalamnya, dan bagiamana peran zakat sebagai sumber keuangan negara.

\section{PEMBAHASAN}

\section{Konsep Dasar Keuangan Publik Islam}

Dalam mengkaji keuangan publik perspektif Islam, maka tidak dapat dipisahkan dari pemahaman atas konsep negara dalam kerangka kerja Islam itu sendiri. Para sarjana Muslim mengartikan negara sebagai entitas politik yang bertanggung jawab terhadap urusan kolektif masyarakat muslim bukan hanya terkait dengan urusan duniawi melainkan juga ukhrawi. Menurut Monzer Kahf

1 Adiwarman Azwar Karim, 2010, Sejarah Pemikiran Ekonomi Islam, Edisi Ketiga, (Jakarta: PT Raja Grafindo Persada), hal. 59-60 
bahwa persoalan keuangan publik yang mencakup pendapatan publik (public revenues) dan pembelanjaan publik (public expenditure) memiliki dua kriteria, yaitu (1) untuk melayani dengan baik kepentingan-kepentingan seluruh anggota komunitas Muslim, dan (2) untuk mengatur kepentingan tersebut berdasarkan sumber-sumber kewahyuan yaitu Al-Qur'a dan Hadist. ${ }^{2}$

Keuangan publik Islam mencakup dua hal yaitu sektor penerimaan dan pengeluaran. Sebelum berlanjut pada pembahasan kedua sektor tersebut, perlu diketahui bahwasannya Islam memiliki prinsip-prinsip kebijakan ekonomi Islam yang menjadi landasan dari aktifitas perekonomian antara lain: (Karim, 2001) $)^{3}$

1. Kekuasaan tertinggi adalah milik Allah dan Allah adalah pemilik yang absolut atas semua yang ada.

2. Manusia merupakan pemimpin (khalifah) Allah di bumi tetapi bukan pemilik yang sebenarnya.

3. Semua yang dimiliki dan didapatkan manusia adalah karena seizin Allah, oleh karena itu golongan yang kurang beruntung memiliki hak atas sebagian kekayaan yang dimiliki oleh golongan yang lebih beruntung.

4. Kekayaan tidak boleh ditumpuk terus atau ditimbun.

5. Kekayaan harus diputar.

6. Eksploitasi ekonomi dalam segala bentuknya harus dihilangkan.

7. Menghilangkan jurang pembeda antar individu dalam perekonomian dapat menghapus konflik antar golongan dengan cara membagikan kepemilikan seseorang setelah kematiannya kepada ahli warisnya.

8. Menetapkan kewajiban yang sifatnya wajib dan sukarela bagi semua individu termasuk bagi anggota masyarakat yang miskin.

Dengan bersandar pada prinsip kebijakan ekonomi Islam di atas, maka prinsip-prinsip yang mendasari baik penerimaan dan pengeluaran keungan publik Islam dapat diuraikan pada pembahasan selanjutnya dalam tulisan ini.

\section{Kebijakan Fiskal Islam}

Dalam pemahaman ekonomi konvensional, kebijakan fiskal merupakan program penerimaan dan pengeluaran pemerintah yang dapat digunakan untuk menstimulasi keadaan ekonomi. Kebijaksanaan fiskal erat kaitannya dengan target keuangan yang ingin dicapai suatu negara. Menurut Mannan kebijakan

${ }^{2}$ Monzer Kahf, 1998, Public Finance and Fiscal Policy in Islam, dalam Monzer Kahf (ed.), Lessons in Islamic Economic, (Qeddah: IDB-IRTI), hal. 455

${ }^{3}$ Adiwarman Azwar Karim, Sejarah Pemikiran Ekonomi Islam, op. cit, hal. 36. 
fiskal adalah langkah pemerintah untuk membuat perubahan-perubahan dalam sistem penerimaan atau dalam pembelanjaan, yang bertujuan untuk mengatasi masalah-masalah ekonomi yang dihadapi negara. Lebih lanjut, prinsip Islam tentang kebijkan fiskal dan anggaran belanja bertujuan untuk mengembangkan suatu masyarakat yang didasarkan atas distribusi kekayaan yang berimbang dengan nilai-nilai material dan spiritual pada tingkat yang sama. ${ }^{4}$ Dari berbagai definisi di atas dapat ditarik kesimpulan, bahwa kebijakan fiskal merupakan bagaimana kebijakan pemerintah mengelola penerimaan dan pengeluaran negara untuk mencapai tujuan-tujuannya. Oleh karena instrumen yang digunakan dalam kebijakan fiskal adalah penerimaan dan pengeluaran negara, maka kebijakan fiskal erat kaitannya dengan target keuangan negara yang ingin dicapai.

Kebijakan fiskal mendapatkan perhatian serius dalam tatanan ekonomi Islam. Dalam perspektif negara Islam, kebijakan fiskal merupakan salah satu perangkat untuk mencapai maqashid syariah atau tujuan syariah yang dijelaskan Imam Al-Ghazali termasuk meningkatkan kesejahteraan dengan tetap menjaga keimanan, kehidupan, intelektualitas, kekayaan, dan kepemilikan. Selain itu, terpenuhinya pekerjaan dan kepentingan publik bagi rakyat merupakan kewajiban keagamaan dan moral penguasa. Tegaknya suatu negara bergantung pada kemampuan pemerintah mengumpulkan pendapatan atau penerimaan dan mendistribusikannya pada kebutuhan kolektif masyarakat. Kemudian kebijakan fiskal Islam merupakan suatu kewajiban negara dan menjadi hak rakyat, sehingga kebijakan fiskal bukanlah semata-mata sebagai suatu kebutuhan untuk perbaikan ekonomi maupun untuk peningkatan kesejahteraan rakyat saja, akan tetapi lebih kepada penciptaan mekanisme distribusi ekonomi yang adil. Karena hakikat permasalahan ekonomi yang melanda umat manusia adalah berasal dari bagaimana distribusi harta di tengahtengah masyarakat terjadi. Jadi keuangan publik dipandang sebagai suatu amanah bagi pemerintah dan harus diarahkan pada lapisan masyarakat yang kekurangan dan orang-orang miskin, sehingga tercipta kesejahteraan dan keadilan.

${ }^{4}$ Muhammad Abdul Mannan, 1997, Teori dan Praktek Ekonomi Islam, Terjemahan. M. Nastangin, (Yogyakarta: PT Dana Bhakti Wakaf), hal. 230 


\section{Landasan Hukum Kebijakan Fiskal}

Landasan hukum kebijakan fiskal salah satunya adalah sebagai berikut:

QS. Al-Anfal: 41

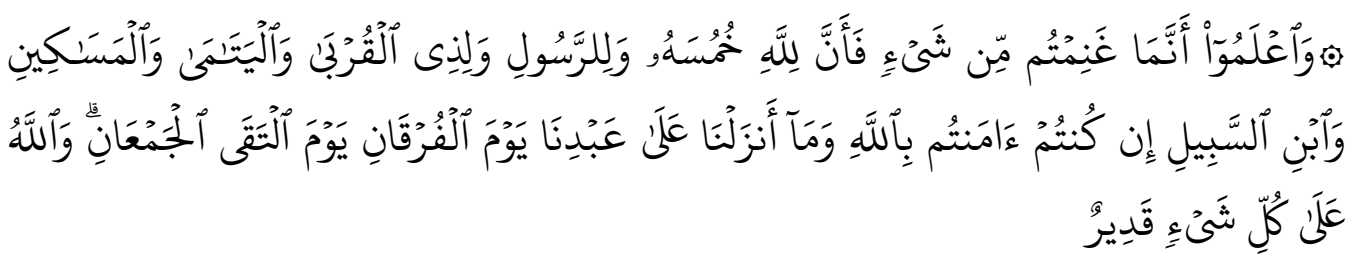

"Ketahuilah, sesungguhnya apa saja yang dapat kamu peroleh sebagai rampasan perang, maka sesungguhnya seperlima untuk Allah, Rasul, kerabat Rasul, anak-anak yatim, orang-orang miskin dan ibnu sabil, jika kamu beriman kepada Allah dan kepada apa yang kami turunkan kepada hamba Kami (Muhammad) di hari Furqaan, yaitu di hari bertemunya dua pasukan. Dan Allah Maha Kuasa atas segala sesuatu".

Menurut Al-Qurthuby bahwa telah terjadi kesepakatan di kalangan para ulama bahwa yang dimaksud dengan maa ghanimtum pada ayat ini adalah harta orang kafir yang diraih kaum Muslimin akibat mengalahkan mereka dalam peperangan. Maksud Al-Qurthuby adalah harta rampasan perang yang diperoleh kaum Muslimin setelah memerangi musuh agama yang kafir. Ayat di atas menyebut enam pihak yang kepada mereka dibagikan seperlima dari harta rampasan perang, tetapi tidak merinci bahkan tidak menyebut kepada siapa diberi empat perlima sisanya. Para ulama sepakat menyatakan bahwa empat perlima itu adalah untuk yang terlibat dalam peperangan itu. Yang dimaksud dengan dzil qurbaa adalah kerabat Rasul SAW, ketetapan Allah memberi bagian dari ghanimah buat kerabat Rasul SAW adalah sebagai penghormatan kepada Rasul SAW dan sebagai imbalan atas ketetapan Rasul SAW yang mengharamkan keluarga beliau memperoleh zakat. Abu Hanifah menegaskan bahwa pemberian itu baru menjadi hak keluarga nabi SAW jika mereka miskin

\section{Sumber Penerimaan dan Pengeluaran Negara dalam Islam}

Mengenai penerimaan publik Islam dapat ditunjukkan bervariasinya bentuk-bentuk sumber pendanaan publik, baik yang sudah ditentukan oleh pemerintah saat itu seperti zakat, kharaj, khums, jizyah, ushur dan sebagainya. Dari berbagai bentuk instrumen penerimaan publik tersebut, maka dapat dianalisa secara ekonomi prinsip dasar pemungutan dana publik pada awal Islam tersebut dapat dilihat pada tabel berikut ini: 


\section{Tabel 1. Sumber Penerimaan Negara dalam Perspektif Islam pada Masa}

\section{Rasul}

\begin{tabular}{|l|l|l|}
\hline Dari Kaum Muslimin & Dari Non-muslim & \multicolumn{1}{|c|}{ Dari Sumber Lain } \\
\hline 1. Zakat & 1. Jizyah & 1. Ghanimah \\
2. Ushur & 2. Kharaj & 2. Fai \\
3. Zakat Fitrah & 3. Ushur & 3. Uang Tebusan \\
4. Wakaf & & 4. Hadiah dari pemimpin lain \\
5. Amwal Fadhla & & dan negara lain \\
6. Nawaib & & 5injaman dari kaum \\
7. Sedekah & & \\
8. Khums & & \\
\hline
\end{tabular}

Sumber: Karim, 2010

Adapun penjelasan mengenai sumber dana penerimaan pada seperti yang di atas antara lain:

\section{1) Zakat}

Pusat dari sumber keuangan negara dalam ekonomi Islam adalah zakat. Pendapatan zakat didistribusikan untuk para mustahik yang meliputi delapan golongan (asnab). Zakat sebagai sumber penerimaan utama memiliki potensi yang besar mengingat hukumnya yang wajib. Selain itu objek zakat dalam dunia modern saat ini bertambah luas dengan dimungkinkannya menarik zakat profesi selain zakat pertanian dan peternakan, zakat perusahaan dan sebagainya. Ajaran Islam dengan rinci telah menentukan syarat, kategori harta yang harus dikeluarkan zakatnya, dan lengkap dengan tarifnya. Pemerintah juga dapat memperluas objek yang wajib dizakati dengan berpegang pada nash umum yang ada dan pemahaman terhadap realita modern.

Jika kita berbicara dalam konteks negara Indonesia, yang merupakan populasi Muslim terbesar di dunia. Maka pemerintah harus serius dalam mengoptimalkan potensi zakat ini karena berdasarkan kajian-kajian emperik yang dilakukan seperti dari BAZNAS Indonesia pada tahun 2017 bahwa Indonesia mempunyai potensi zakat mencapai Rp 217 Triliun. $^{5}$ Meskipun telah banyak lembaga zakat baik dari pemerintah dan swasta. Namun dalam hal pemungutan zakat masih belum mencapai target sesuai dengan potensi zakat yang telah disebutkan tadi, karena beberapa faktor yang mempengaruhinya.

2) Wakaf

${ }^{5}$ Badan Amil Zakat Nasional, 2018, Statistik Zakat Nasional 2017, (Jakarta: Tim Bagian Liaison dan Pelaporan, BAZNAS), hal. iii 
Wakaf secara bahasa memiliki arti berhenti atau berdiri dan secara istilah adalah atau menahan harta yang diambil manfaatnya tanpa menghabiskan bendanya (ainnya) yang digunakan untuk kemaslahatan. Dimana dalam hal kepemilikan objek wakaf dikembalikan pada Allah swt. Oleh karena itu, barang yang diwakafkan tidak boleh habis, diberikan atau dijual kepada pihak lain. Harus berkelanjutan dan berkesinambungan. Dalam menunaikan wakaf, bisa dilakukan dengan harta bergerak maupun tidak bergerak. Mazhab Maliki membuka kesempatan untuk memberikan wakaf dalam jenis aset apa pun, termasuk yang paling likuid, yaitu dalam bentuk uang tunai.

3) Nawaib

Nawaib merupakan pajak umum yang dibebankan atas warga negara untuk menanggung kesejahteraan sosial atau kebutuhan dana untuk situasi darurat. Pajak ini dibebankan pada kaum muslim yang kaya dalam rangka menutupi pengeluaran negara selama masa darurat.

4) Jizyah

Jizyah merupakan pajak yang dibayar oleh kalangan non-muslim sebagai kompensasi atas fasilitas (jaminan) sosial ekonomi, layanan kesejahteraan, serta jaminan keamanan yang mereka terima dari negara Islam. Jizyah diambil dari orang-orang non-muslim selama mereka tetap pada kepercayaannya. Namun apabila mereka telah memeluk agama Islam, maka kewajiban membayar jizyah tersebut gugur. Jizyah tidak wajib jika orang kafir yang bersangkutan tidak mempunyai kemampuan membayarnya karena kefakiran atau kemiskinannya.

5) Kharaj

Kharaj adalah pajak atas tanah yang dimiliki kalangan non-muslim di wilayah negara muslim. Tanah yang pemiliknya masuk Islam, maka tanah itu menjadi milik

mereka dan dihitung sebagai tanah 'usyr seperti tanah yang dikelola di kota Madinah dan Yaman. Penentuan besarnya kharaj ditentukan oleh karakteristik tanah, jenis tanaman, dan jenis irigasi.

6) Khums

Khums adalah dana yang diperoleh dari seperlima bagian rampasan perang. Khums juga merupakan suatu sistem pajak proporsional, karena ia adalah persentase tertentu dari rampasan perang yang diperoleh tentara Islam sebagai ghanimah setelah memenangkan peperangan. Persentase tertentu dari pendapatan sumber daya alam, barang tambang, minyak bumi dan barangbarang tambang lainnya juga dikategorikan khums.

7) 'Ushur (Pajak Perdagangan) 
Dalam hal ini 'ushur adalah pajak yang dikenakan atas barang-barang dagangan yang masuk negara Islam, atau datang dari negara Islam sendiri. Pajak ini berbentuk bea impor yang dikenakan pada semua pedagang, dibayar sekali dalam setahun dan hanya berlaku bagi barang yang nilainya lebih dari 200 dirham. Permulaan ditetapkannya 'ushur di negara Islam adalah di masa khalifah dengan landasan penegakan keadilan, karena 'ushur dikenakan pada para pedagang muslim ketika mereka mendatangi daerah asing. Tempat berlangsungnya pemungutan 'ushur adalah pos perbatasan negara Islam, baik pintu masuk maupun pintu keluar

sebagaimana bea cukai pada saat ini.

8) Pinjaman

Pinjaman atau utang, baik yang berasal luar negeri maupun dalam negeri dalam Islam sifatnya adalah hanya sebagai penerimaan sekunder. Alasannya, ekonomi Islam tidak mengenal bunga, demikian pula untuk pinjaman dalam Islam haruslah bebas bunga, sehingga pengeluaran pemerintah akan dibiayai dari pengumpulan pajak atau bagi hasil. Dalam pengertian ini, Islam tidak melarang untuk melakukan utangpiutang asalkan tidak membebani pengutang, karena sifatnya hanya membantu dan harus segera diselesaikan dalam waktu yang singkat.

9) Amwal Fadha

Yaitu harta benda kaum muslimin yang meninggal tanpa ahli waris, atau berasal dari barangbarang seorang Muslim yang meninggalkan negerinyaharta benda kaum muslimin yang meninggal tanpa ahli waris, atau berasal dari barangbarang seorang Muslim yang meninggalkan negerinya.

Secara umum terdapat kaidah-kaidah Syar'iyah yang membatasi kebijakan pendapatan Negara. Kahf berpendapat sedikitnya ada tiga prosedur yang dilakukan pemerintah Islam modern dalam kebijakan pendapatan fiskalnya dengan asumsi bahwa pemerintah tersebut sepakat dengan adanya pungutan pajak (terlepas dari ikhtilaf ulama mengenai pajak), antara lain: ${ }^{6}$

1. Kaidah syar'iyyah yang berkaitan dengan kebijakan pungutan zakat

Pemerintah tidak berhak untuk mengubah ketentuan zakat sebagaimana yang telah ditentukan oleh ajaran Islam. Akan tetapi

${ }^{6}$ Mustafa Edwin Nasution, et. Al, 2006, Pengenalan Ekslusif Ekonomi Islam, Cetakan Keenam, (Depok: Kencana-Prenada Media), hal. 221-222 
pemerintah dapat mengadakan perubahan dalam struktur harta yang wajib dizakati dengan berpegang teguh pada nash-nash.

2. Kadah-kaidah syar'iyyah yang berhubungan dengan hasil pendapatan yang berasal dari aset pemerintah.

Pendapatan dari aset pemerintah yang umum berupa investasi aset pemerintah yang dikelola baik oleh pemerintah atau masyarakat. Pendapatan dari aset masyarakat menurut kaidahnya bahwa manusia berserikat dalam memiliki air, api dan garam. Kaidah ini dalam konteks modern adalah sarana-sarana umum yang dibutuhkan oleh masyarakat umum. Dengan demikian kaidah yang digunakan dalam hal ini adalah kaidah tentang maslahah.

3. Kaidah-kaidah syar'iyyah yang berkaitan dengan hasil pendapatan dari pajak..

Pada dasarnya Islam melarang pemungutan secara paksa harta masyarakat Muslim. Pajak dalam ekonomi modern merupakan sektor pendapatan terpenting dan terbesar dengan alasan pajak dialokasikan pada publics goods dan berfungsi sebagai redistribusi, penstabilan, pendorong pertumbuhan ekonomi. Seperti yang diungkapkan oleh Muhammad Baqir Ash-Shadr, bahwa pajak merupakan kewajiban fiskal yang tidak hanya digunakan untuk memenuhi kebutuhan pokok saja, namun dimaksudkan untuk menanggulangi kemiskinan dan meningkatkan standar hidup kaum miskin untuk merealisasikan keseimbangan sosial seperti yang dicita-citakan oleh Islam.

Berdasarkan analisis ekonomi terhadap sejarah pengeluaran publik Islam semasa Rasulullah SAW dan Khulafaur Rasyidin serta kaidah fiqh muamalah, pada hakikatnya prinsip utama dalam pengalokasian dana publik adalah peningkatan maslahat tertinggi. Berkaitan tentang pengeluaran negara selama masa pemerintahan Rasululullah SAW secara sistematis digunakan untuk halhal tertentu dan tersebut di bawah ini akan dijelaskan: (Karim, 2010) ${ }^{7}$

\section{Tabel 2. Pengeluaran Negara dalam Islam pada Masa Rasul}

\begin{tabular}{|c|c|}
\hline Pengeluaran Primer & Pengeluaran Sekunder \\
\hline $\begin{array}{l}\text { a. Biaya pertahanan seperti } \\
\text { persenjataan, dan persediaan } \\
\text { b. Penyaluran zakat dan ushur kepada }\end{array}$ & $\begin{array}{l}\text { a. Bantuan untuk orang yang belajar } \\
\text { agama di Madinah } \\
\text { b. Jamuan untuk delegasi keagamaan, }\end{array}$ \\
\hline
\end{tabular}

\footnotetext{
${ }^{7}$ Adiwarman Azwar Karim, Sejarah Pemikiran Ekonomi Islam, op. cit, hal. 51
} 
yang berhak menerimanya

c. Pembayaran gaji untuk wali, qady, guru, imam, dan pejabat negara

d. Pembayaran upah para sukarelawan

e. Pembayaran utang negara

f. Bantuan untuk musafir (dari daerah fadak) utusan suku dan negara serta biaya perjalanan

c. Hadiah untuk pemerintah negara lain

d. Pembebasan kaum muslimin yang menjadi budak

e. Pembayaran denda atas mereka yang terbunuh secara tidak sengaja oleh pasukan kaum muslimin

f. Pembayaran utang orang yang meninggal dalam keadaan miskin

g. Pembayaran tunjangan untuk orang miskin Tunjangan untuk sanak saudara Rasulullah

h. Pengeluaran rumah tangga Rasulullah saw

i. Persediaan darurat

Sumber: Karim, 2010

Secara umum, belanja negara dapat dikategorikan menjadi empat:

1. Pemberdayaan fakir miskin dan muallaf. Dana ini pada umumnya diambil dari zakat dan $u s h r$.

2. Biaya rutin pemerintahan. Dana ini pada umumnya diambilkan dari kharaj, fai', jizyah dan ushr.

3. Biaya pembangunan dan kesejahteraan sosial. Dana ini pada umumnya diambilkan dari dana lainnya, khums, dan sedekah.

4. Biaya lainnya, seperti biaya emergency, pengurusan anak telantar dan sebagainya. Dana ini pada umumnya diambilkan dari waqaf, utang publik dan sebagainya.

Kebijakan belanja pemerintah dalam sistem ekonomi Islam dapat dibagi menjadi tiga bagian antara lain:

1. Belanja kebutuhan operasional pemerintah yang rutin.

2. Belanja umum yang dapat dilakukan pemerintah apabila sumber dananya tersedia.

3. Belanja umum yang berkaitan dengan proyek yang disepakati oleh masyarakat berikut sistem pendanaannya.

Adapun kadiah-kaidah Syar'iyyah yang berhubungan dengan belanja kebutuhan operasional pemerintah yang rutin adalah mengacu pada kaidah- 
kaidah yang telah disebutkan di atas. Secara rinci pembelanjaan negara harus didasarkan pada:

1. Kebijakan belanja rutin harus didasarkan pada kemaslahatan umum dan tidak boleh hanya disandarkan pada kemaslahatan individu atau kelompok semata.

2. Kaidah atau prinsip efisiensi dalam belanja rutin yaitu mendapatkan sebanyak mungkin manfaat dengan biaya yang semurah-murahnya. Kaidah ini akan membawa pemerintah jauh dari sifat mubadzir dan kikir di samping alokasinya pada sektor-sektor yang tidak bertentangan dengan Syari'ah.

3. Tidak berpihak pada kelompok kaya dalam pembelanjaan, walaupun dibolehkan berpihak pada kelompok miskin.

4. Prinsip komitmen dengan aturan Syari'ah, maka alokasi belanja negara hanya boleh pada hal-hal yang mubah dan menjauhi yang haram.

5. Prinsip komitmen dengan skala prioritas Syari'ah, dimulai dai yang wajib, sunnah, mubah atau dharurah, hajiyyat dan kamaliyah.

Menurut Abdurrahman Al-Maliki, kebijakan fiskal dalam Islam tidak terlepas dari kendali politik ekonomi (assiyasatul iqtishodi) yang bertujuan untuk menjamin pemenuhan kebutuhan-kebutuhan primer setiap individu secara menyeluruh, dan membantu tiap-tiap individu di antara mereka dalam memenuhi kebutuhan-kebutuhan sekunder dan tersiernya sesuai kadar kemampuannya. ${ }^{8}$ Jaminan pemenuhan kebutuhan primer meliputi; pertama pemenuhan kebutuhan primer bagi tiap-tiap individu seperti sandang, pangan, papan. Kedua, jaminan kebutuhan primer bagi rakyat secara keseluruhan meliputi keamanan, pendidikan dan kesehatan. Dapat diketahui, kebutuhan tiga unsur ini sangat berperan penting bagi perekonomian.

Dengan demikian dapat dilihat bahwa Islam memandang kesejahteraan sosial dan individu sebagai dua hal yang saling melengkapi, bukan kompetitif dan antagonistik. Karena itu, Islam memandang bahwasanya kebaikan seseorang atau individu sebagai kebaikan masyarakat dan sebaliknya. Islam tidak memisahkan perseorangan dengan masyarakatnya, atau memandang kesejahteraannya bertentangan dengan kepentingan umum. Karena ini merupakan kewajiban bagi pemerintah untuk menyediakan dan membagikan sarana kebutuhan antar warga secara merata menurut kebutuhannya secara adil.

${ }^{8}$ Abdurrahman Al-Maliki, 2001, Politik Ekonomi Islam, (As-Siyasatu al-Iqtishadiyatu al-Mutsla), Alih bahasa Ibnu Sholah, Cetakan kesatu, (Bangil: Al-Izzah), 


\section{Tabel 3. Sumber Keuangan Islam}

\begin{tabular}{|l|l|}
\hline \multicolumn{1}{|c|}{ PENERIMAAN } & \multicolumn{1}{c|}{ PENGELUARAN } \\
\hline Zakat & Kebutuhan Dasar \\
\hline Kharaj & Kesejahteraan Sosial \\
\hline Jizyah & Pendidikan dan Penelitian \\
\hline Ushur Jenis Sukarela & Infrastruktur (Fasilitas Publik) \\
\hline \multicolumn{1}{|c|}{ Jenis Kondisional } & Dakwah Islam \\
\hline Infak Sedekah & Administrasi Negara \\
\hline Wakaf & Pertahanan Keamanan \\
\hline Hibah-Hadiah & \\
\hline & \\
\hline Khums & \\
\hline Pajak & \\
\hline Keuntungan BUMN (Fai') & \\
\hline Lain-lain & \\
\hline
\end{tabular}

Sumber: Huda, et.al, 2012

\section{Zakat Sebagai Instrumen Utama Keuangan Negara}

Salah satu upaya dan kewajiban negara adalah mengatur ekonomi dengan tujuan untuk menjamin masyarakatnya mencapai kesejahteraan. Baqir AshShadr melihat bahwa intervensi negara dalam kehidupan ekonomi sangat diperlukan untuk menjamin keselarasannya dengan norma-norma Islam tersebut (Chapra, 2001). ${ }^{9}$ Karena itu pemerintah berperan menyediakan berbagai barang publik untuk mendorong pembangunan dan kesejahteraan bersama melalui kebijakan publik dan fiskalnya.

Zakat merupakan ciri sistem ekonomi Islam, ini karena zakat merupakan salah satu implementasi asas keadilan dalam sistem ekonomi. Mannan mengatakan zakat mempunyai enam prinsip: ${ }^{10}$

1. Prinsip keyakinan dalam beragama, artinya bahwa orang yang membayar zakat merupakan salah satu bentuk manifestasi dari keyakinan dalam beragama.

9 Umer Chapra, 2001, The Future of Economics: An Islamic Perspectif, Edisi Terjemahan, (SEBI Institute: Jakarta),

${ }^{10}$ Muhammad Abdul Mannan, Teori dan Praktek Ekonomi Islam, op. cit, 
2. Prinsip pemerataan dan keadilan, ini merupakan tujuan sosial dari zakat, yaitu melakukan distribusi kekayaan yang telah diberikan Allah lebih adil dan merata kepada sesama manusia.

3. Prinsip produktivitas, artinya bahwa zakat memang harus dibayar karena milik tertentu telah menghasilkan produk tertentu setelah lewat jangka waktu tertentu (Nisab dan Haulnya).

4. Prinsip nalar, sangat rasional bahwa zakat harta yang menghasilkan itu harus dikeluarkan.

5. Prinsip kebebasan, zakat hanya dibayar oleh orang yang bebas.

6. Prinsip etika dan kewajaran, yaitu zakat tidak dipungut secara semenamena.

Menurut Kahf (1999), tujuan utama dari zakat adalah untuk mencapai keadilan sosial ekonomi. Zakat merupakan transfer sederhana dari bagian dengan ukuran tertentu harta si kaya untuk dialokasikan kepada fakir dan miskin. ${ }^{11}$ Kemudian Muhammad Daud Ali menjelaskan bahwa tujuan zakat adalah: ${ }^{12}$

(1) Mengangkat derajat fakir miskin.

(2) Membantu memecahkan masalah para gharimin, ibnu sabil, dan mustahik lainnya.

(3) Membina tali persaudaraan sesama umat Islam dan manusia pada umumnya.

(4) Menghilangkan sifat kikir para pemilik harta.

(5) Menghilangkan sifat iri dan dengki bagi orang-orang fakir dan miskin.

(6) Menjembatani antara si kaya dan si miskin.

(7) Mengembangkan rasa tanggung jawab sosial pada diri orang yang memiliki kelebihan harta.

(8) Mendidik manusia untuk senantiasa menunaikan kewajiban.

(9) Sarana pemerataan pendapatan untuk mencapai keadilan sosial.

Sebagai suatu komponen utama dalam keuangan publik Islam serta kebijakan fiskal dalam sistem ekonomi Islam. Zakat merupakan kegiatan wajib untuk semua umat Islam serta merupakan elemen penting dalam sumber pendapatan negara. Zakat adalah ketentuan yang wajib dalam sistem ekonomi (obligatory zakat system) sehingga dalam pelaksanaannya dilakukan melalui

${ }^{11}$ Monzer Kahf, 1999, The Principle of Socioeconomics Justice in The Contemporary Fiqh of Zakah, Iqtisad, Journal of Islamic Economics, Vol. 1

${ }^{12}$ Muhammad Daud Ali, 1988, Sistem Ekonomi Islam Zakat dan Wakaf, (Jakarta: UI Press). 
institusi resmi atau legal. Maka pengumpulan, pengelolaan, dan pendistribusian bisa tepat sasaran.

Implikasi zakat dalam arti khusus, dalam hal ini ekonomi, yaitu: Pertama, zakat dapat memenuhi kebutuhan-kebutuhan mayarakat yang memiliki kekurangan. Kedua, zakat dapat memperkecil jurang kesenjangan ekonomi, antara si kaya dan si miskin. Ketiga, zakat secara tidak langsung dapat menekan jumlah permasalahan sosial, kriminalitas, dan lain-lain. Keempat, zakat dapat menjaga kemampuan daya beli masyarakat agar dapat memelihara sektor usaha, artinya dengan zakat maka konsumsi masyarakat terjaga pada tingkat yang minimal (dapat terkontrol), sehingga perekonomian dapat berjalan dengan baik.

Maka di sinilah pentingnya pemerintah dalam mendorong masyarakat membayar zakat kepada Badan Amil Zakat Nasional atau LAZ Tertentu yang telah didirikan di seluruh provinsi, kabupaten dan kecamatan. Artinya dengan melakukan pemusatan dalam penghimpunan zakat, maka dana yang didapat akan mudah untuk disalurkan. Sehingga potensi zakat yang besar di Indoensia tersebut dapat dikelola dengan baik dan paling penting tepat sasaran. Dengan demikian, zakat berusaha meningkatkan taraf hidup masyarakat fakir dan miskin ke tingkatan hidup yang lebih layak. Zakat juga merupakan sarana untuk mendekatkan jurang pemisah antara orang kaya dengan fakir dan miskin (Qardhawi, 1996). ${ }^{13}$

Terkait masalah fundamental yang bernama kemiskinan tetap menjadi tanggung jawab negara. Menurut Islam, dalam pemberantasan kemiskinan, negara harus melakukan intervensi dalam masalah ini. Dalam Al-Qur'an diajarkan prinsip al-ma'un atau tanggung jawab sosial dapat diwujudkan ke dalam lembaga-lembaga negara, sebab kalau tidak maka seluruh masyarakat dapat terkena predikat "mendustakan agama". Negara sebenarnya hanya bertugas menjamin terlaksananya ajaran ini, apakah dengan tindakan yang lebih langsung atau mendorong swasta dan masyarakat sendiri untuk melaksanakan doktrin itu.

Para pemikir Islam pada umumnya cenderung untuk menempatkan peranan negara yang aktif, baik dalam mengendalikan perekonomian ke arah perkembangan yang lebih stabil, terutama untuk mencegah pengangguran, mengarahkan alokasi sumber daya sehingga dapat dicapai keseimbangan antara efisiensi dan partisipasi masyarakat yang luas dalam kegiatan usaha serta melakukan redistribusi pendapatan dan kekayaan masyarakat sehingga tidak timbul kepincangan dan ketidakadilan sosial. Kemiskinan merupakan suatu fenomena yang amat kompleks. Sehingga dengan demikian, kemiskinan tidak saja menyangkut problem kultural, tetapi juga problem structural yang

${ }^{13}$ Yusuf Al-Qardhawi, 1996, Haruskah Hidup dengan Riba, (Jakarta: Gema Insani Press) 
menyangkut bagaimana negara membuat kebijakan fiskal yang berorientasi pada penanggulangan kemiskinan Secara kultural, Islam menganjurkan untuk menumbuhkan peranan setiap individu dalam meningkatkan kualitas hidupnya dan menumbuhkan proses kebersamaan sosial (kepedulian) melalui zakat, infak, sedekah dan instrumen lain. Islam meletakkan peran sentral negara dalam menciptakan distribusi pendapatan dan kekayaan masyarakat secara adil dan merata dan menjaga stabilitas dan keberlangsungan perkembangan ekonomi dalam proses kemajuan dan pemerataan serta sebagai fasilitator pemberdayaan masyarakat dalam mencari solusi ke taraf hidup yang lebih layak.

\section{KESIMPULAN}

Dalam Islam, kebijakan fiskal merupakan suatu kewajiban negara dan menjadi hak rakyat sehingga kebijakan fiskal bukanlah semata-mata sebagai suatu kebutuhan untuk perbaikan ekonomi maupun untuk peningkatan kesejahteraan rakyat, tetapi lebih pada penciptaan mekanisme distribusi ekonomi yang adil. Pembelanjaan pemerintah dalam koridor Negara Islam berpegang pada terpenuhinya semua kebutuhan primer (basic needs) tiap-tiap individu dan kebutuhan sekunder dan kebutuhan pelengkap (alhajat alkamaliyah) sesuai kadar kemampuannya sebagai individu yang hidup dalam masyarakat. Dengan penjaminan kebutuhan primer, Negara telah membangun suatu infrastruktur ekonomi dengan distribusi ekonomi yang adil, karena orangorang yang kurang memiliki kemampuan dari sisi ekonomi disantuni oleh negara dengan penjaminan pemenuhan kebutuhan-kebutuhan pokoknya. Juga setiap orang mendapatkan hak yang sama dalam keamanan akan hartanya, akan usahanya (pertanian, industri dan perdagangan, jasa, dan lain-lain), jiwanya dan keluarganya. Dengan demikian, keuangan publik yang dipraktekkan pada masa Islam awal memiliki basis yang jelas pada filsafat etika dan sosial Islam yang menyeluruh.

Fungsi dari pemerintah Islam yang modern tidak lagi terbatas pada fungsi seperti yang dijalankan oleh pemerintah Islam terdahulu yang bertumpu pada satu aspek. Corak perekonomian sekarang telah berubah dan sumber pendapatan yang relatif lebih layak dan lebih terdiversifikasi telah tersedia bagi pemerintah modern. Perbedaan konteks ini menyebabkan banyak sumbersumber pendapatan yang dulu sangat berarti seperti fai', ghanimah, jizyah sudah tidak relevan lagi. Namun demikian, pemerintahan Islam yang modern semestinya menggali dari sumber-sumber lain serta melakukan kebijakankebijakan strategis yang sesuai dengan prinsip-prinsip ekonomi Islam dan dalam operasionalnya tetap patuh pada syariah. Dengan melakukan terobosanterobosan yang progresif serta taat syariah diharapkan pendapatan negara akan optimal serta kesejahteraan rakyat akan terjamin. 


\section{DAFTAR PUSTAKA}

Ali, Muhammad Daud (1988): Sistem Ekonomi Islam Zakat dan Wakaf, Jakarta: UI Press.

Al-Maliki, Abdurrahman (2001): Politik Ekonomi Islam, (As-Siyasatu alIqtishadiyatu al-Mutsla), Alih bahasa Ibnu Sholah, Cetakan kesatu, Bangil: Al-Izzah.

Yusuf, Al-Qardhawi (1996): Haruskah Hidup dengan Riba, Jakarta: Gema Insani Press.

Badan Amil Zakat Nasional (2018): Statistik Zakat Nasional 2017, Jakarta: Tim Bagian Liaison dan Pelaporan BAZNAS.

Umer, Chapra (2001): The Future of Economics: An Islamic Perspectif, Edisi Terjemahan, Jakarta: SEBI Institute.

Huda, Nurul, dkk (2012): Keuangan Publik Islam: Pendekatan Teoritis dan Sejarah, Jakarta: Kencana.

Kahf, Monzer (1998): Public Finance and Fiscal Policy in Islam, dalam Monzer Kahf (ed.), Lessons in Islamic Economic, Qeddah: IDB-IRTI.

Kahf, Monzer (1999): The Principle of Socioeconomics Justice in The Contemporary Fiqh of Zakah, Iqtisad, Journal of Islamic Economics, Vol. 1 .

Karim, Adiwarman Azwar (2010): Sejarah Pemikiran Ekonomi Islam, Edisi Ketiga, Jakarta: PT Raja Grafindo Persada.

Mannan, Muhammad Abdul (1997): Teori dan Praktek Ekonomi Islam, Terjemahan. M. Nastangin, Yogyakarta: PT Dana Bhakti Wakaf.

Nasution, Mustafa Edwin, dkk (2006): Pengenalan Ekslusif Ekonomi Islam, Cetakan Keenam, Depok: Kencana-Prenada Media. 